\title{
Reference value and annual trend of white blood cell counts among adult Japanese population
}

\author{
Sonoko Sakuragi $\cdot$ Jiro Moriguchi $\cdot$ \\ Fumiko Ohashi $\cdot$ Masayuki Ikeda
}

Received: 7 August 2012/Accepted: 27 August 2012/Published online: 30 September 2012

(C) The Japanese Society for Hygiene 2012

\begin{abstract}
Objectives This study was initiated to establish the reference values (the $95 \%$ lower limit in particular) for white blood cell (WBC) counts in peripheral blood of general Japanese population. Additional attempts were made to examine whether the reference range had changed in the past 100 years, and which factors had induced such change in WBC counts.

Methods Data employed were WBC counts of $>100$ thousand apparently healthy Japanese men, collected in 2002 and in 2010, respectively. Information on smoking habits was collected simultaneously.

Results The distribution of WBC counts was essentially normal. Arithmetic mean (AM) WBC was 6,248 cells $/ \mathrm{mm}^{3}$ in 2002 and 6,162 cells $/ \mathrm{mm}^{3}$ in 2010. Based on the 2010 observation, $3 \times 10^{3} \mathrm{WBCs} / \mathrm{mm}^{3}$ (after rounding of the figure) was identified as the $95 \%$ lower limit of the reference value for the population. No clear age dependency was detected. Smoking induced elevation in WBC, whereas WBC returned to the level of never smokers after quitting for 3 or more years.

Conclusions Historical review disclosed a secular trend of decrease in WBC in the past 100 years, so that about $8 \%$ of never-smoking men would be considered leukocytopenic according to the conventional cutoff of $4 \times 10^{3}$ cells $/ \mathrm{mm}^{3}$ as a screening level. Decreased smoking rates and improved general hygiene are discussed as possible factors for WBC
\end{abstract}

S. Sakuragi · J. Moriguchi

Kyoto Industrial Health Association (Mibu Office),

4-1 Mibu-Shijaku-cho, Nakagyo-ku, Kyoto 604-8471, Japan

F. Ohashi · M. Ikeda ( $\square)$

Kyoto Industrial Health Association (Main Office),

67 Nishinokyo-Kitatsuboicho, Nakagyo-ku,

Kyoto 604-8472, Japan

e-mail: ikeda@hokenkai.jp count reduction. Thus, WBC count of $3 \times 10^{3}$ cells $/ \mathrm{mm}^{3}$ is recommended as the $95 \%$ lower limit of the reference value for screening cases with reduced WBC counts.

Keywords Annual trend - Japanese - Leukocyte counts . Men $\cdot$ Reference value $\cdot$ White blood cell counts

\section{Introduction}

Counting of leukocytes [white blood cells (WBCs)], a classical method to detect hematological abnormalities, is still an important item in occupational health examination. For example, whereas benzene-induced leukocytopenia [1] has seldom been encountered recently in industrialized countries including Japan as industrial use of this wellknown hematotoxic solvent has been severely controlled in recent years [2, 3], the WBC count stands as a critical health effect marker in health examination for radiationexposed subjects [4].

In preventive medicine, therefore, establishment of the reference value for WBC counts together with clarification of the range of distribution among Japanese general population are of practical importance. It has been reported that ethnic difference exists in WBC counts among adult women [5] and presumably in general population as a whole, which suggests the need for studies on local populations such as Japanese for evaluation of Japanese subjects.

Substantial compilations of WBC count data for apparently healthy men were available to this study group. Taking advantage of these compilations, this study was initiated to clarify the current levels of WBC counts in general Japanese population. A secular trend of shift in the WBC counts and possible age dependency were also examined in comparison with retrieved reports on WBC 
counts for the Japanese population in the past. Whereas the materials examined were for men, it was expected that the conclusions should be applicable also to women, as there would be no gender difference in WBC counts [6].

\section{Subjects and methods}

The study protocol was approved by the Ethics Committee of Kyoto Industrial Health Association. Each and all of the subjects studied provided informed consent in writing, with understanding that physicians and/or paramedical staff of the Association might use the results of the health examinations for medical education and research purposes under the condition that the results be presented generally on a group basis or with due respect to anonymity of the subjects.

The subjects were apparently healthy adult Japanese men who underwent hematological examinations (including WBC counting) as part of routine annual health checkup in clinical facilities of this Association. Those who were under medical treatments were excluded. In practice, more than 100 and 130 thousand cases were available during the 1-year period from 1 August 2002 to 31 July 2003 (the 2002 data) and during another 1-year period from 1 April 2010 to 31 March 2011 (the 2010 data), respectively. Many of the examinees were full-time employees of enterprises of various sizes, but self-employed people, university students, and local residents were also included.

Blood samples were taken by venopuncture of cubital vein, and immediately heparinized. Hematological examinations were conducted by use of automated blood cell counters. Depending on the survey year, two types of counters were used, i.e., Sysmex SE9000 (Sysmex, Kobe, Japan) in 2002, and ABX PENTRA XL80 (Horiba, Kyoto, Japan) in 2010. A preliminary study with human blood samples to examine possible intercounter difference in the results [7] gave a regression line of $Y=-361+$ $0.993 X(r=0.997, p<0.01, n=97)$, where $X$ and $Y$ are the measures by Sysmex and PENTRA, respectively. This close agreement was taken to suggest that no adjustment was necessary in evaluation. By means of self-administered questionnaires, the subjects were asked in addition on their smoking habits, i.e., if they were current, former, or never smokers; in case of former smokers, they were further asked the duration of smoking abstinence, whether it was less than 3 years or 3 years and longer.

For time trend analysis, literature was sorted by use of a retrieval system, "Ichushi-Web," a system founded by the Japan Medical Abstracts Society (Tokyo, Japan) in 1983 specifically for Japan-based literature published in the 1980s and afterwards; it was found that the target literature was usually in Japanese, for which search by PubMed was not productive enough. Literature published in the 1970s and earlier was traced by taking advantage of references given in published articles. Thus, best efforts were made to collect publications even in the period not covered by the retrieval system.

With regard to statistical analyses, normal distribution was assumed for WBC counts, as discussed later in detail, so that the distributions were expressed in terms of arithmetic means (AMs) and arithmetic standard deviations (ASDs). Unpaired $t$ test and analysis of variance (ANOVA) (followed by post hoc test, Scheffé) were employed to detect possible significance of differences in the distributions. Possible difference in parameters between two regression lines were examined after Ichihara [8].

\section{Results}

Distribution patterns among total subjects, smokers, and nonsmokers

Distribution histograms for total, never-smoking, and currently smoking cases are depicted in Fig. 1a-c, respectively, to show that the distributions were essentially normal. It should be noted that the mode of WBC counts for never smokers [WBC count, about $5.0 \times 10^{3}$ cells $/ \mathrm{mm}^{3}$; Fig. 1b] was slightly smaller than that for current smokers [WBC count; about $6.0 \times 10^{3}$ cells $/ \mathrm{mm}^{3}$; Fig. 1c].

WBC counts in 2002 and in 2010

In practice, 103,492 and 130,431 cases were available in 2002 and 2010, respectively. Breakdown of the total cases by smoking habits to never, former, and current smokers (Table 1) showed that former smokers were older than the other two groups by about 5 years. When WBC counts were compared, WBC counts for the total group in 2010 differed significantly from the counts in $2002(p<0.01)$, but the net difference (a decrease) in AM was as small as 86 cells $/ \mathrm{mm}^{3}$. Similar comparison of WBC for the neversmoker group in 2002 and in 2010 also showed a significant $(p<0.01)$ difference with a small net increase in AM WBC of 57 cells $/ \mathrm{mm}^{3}$. It was considered that both changes were medically meaningless, although statistically significant due to the large numbers of cases studied (i.e., $>30,000$ cases even for never smokers).

WBC counts for current smokers were significantly higher $(p<0.01)$ than those for never or former smokers in both 2002 and 2010. The net difference was about 1,000 cells/ $\mathrm{mm}^{3}$. In contrast, the net difference between former and never smokers was quite smaller, e.g., about 100 cells $/ \mathrm{mm}^{3}$, although it was statistically significant $(p<0.01)$.

Further calculation for 5 percentile values to find the $95 \%$ lower limit of the WBC counts (Table 1) revealed 


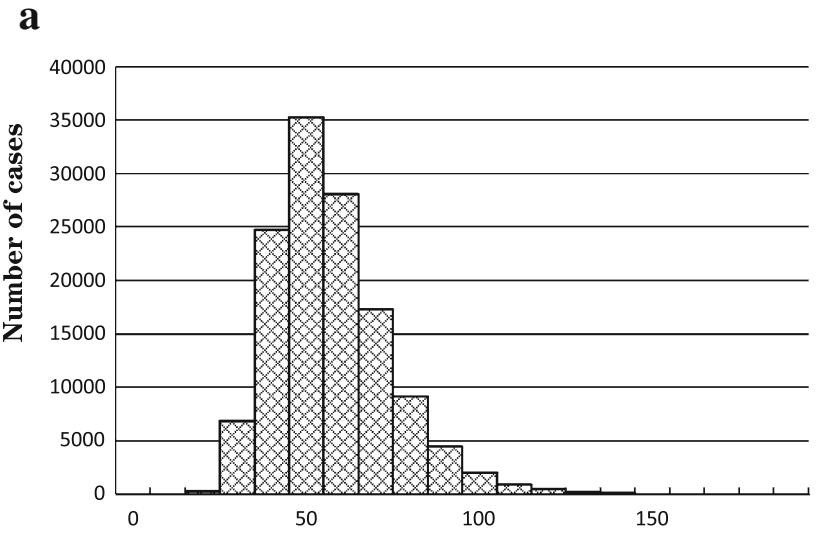

b

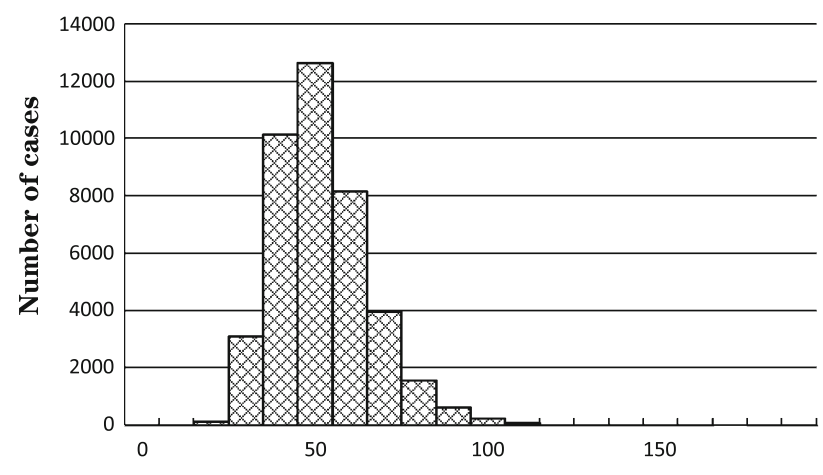

c

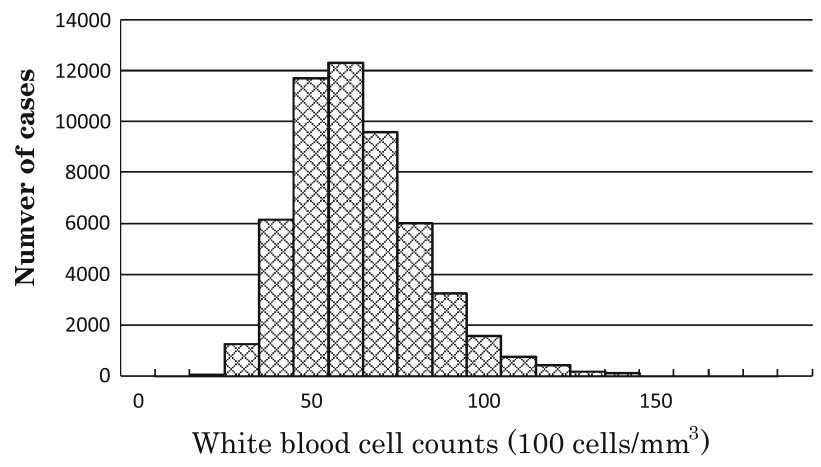

Fig. 1 Distribution histograms of white blood cell counts among Japanese men, as studied in 2010: a total cases, b never smokers, c current smokers

that, in 2010 , the values were $2,899,2,925$, and 3,123 cells/ $\mathrm{mm}^{3}$ for never, former, and current smokers, respectively. After rounding the figures, $3.0 \times 10^{3}$ cells $/ \mathrm{mm}^{3}$ would be the $95 \%$ lower limit of the current reference for general population including current smokers.

Effect of abstinence of smoking

Analysis of 2010 data on the duration of abstinence of smoking showed that AM WBC counts for those with abstinence for 3 years or longer $\left(5,591 \mathrm{cells} / \mathrm{mm}^{3}\right.$; $n=603)$ did not differ significantly ( $p>0.10$ by Scheffé) from the values for never smokers $\left(5,666\right.$ cells $/ \mathrm{mm}^{3}$; $n=40,748)$, whereas AM WBC for those who had quit for less than 3 years $\left(5,753\right.$ cells $\left./ \mathrm{mm}^{3} ; n=35,438\right)$ was still more than that for never smokers.

Possible effect of aging

To examine possible age-dependent changes in WBC counts, total cases were divided by decades of age, and 7 age groups were subjected to ANOVA (Table 2). It should be noted that the cases at $80+$ years of age were limited, i.e., 48 and 11 cases in 2002 and 2010, respectively $(<0.05 \%$ of the cases studied). It turned out that there was a steady trend of decrease in the three youngest age groups in both 2002 and 2010. For older ages, however, the changes were in the opposite direction in the 50-59-year group in 2002 and insignificant in 2010. In addition, the net difference between the age groups was $<150$ cells $/ \mathrm{mm}^{3}$. In overall evaluation, therefore, it was concluded that the agedependent changes should be not meaningful medicobiologically, although statistically significant in some cases.

\section{Discussion}

The present analysis has made it clear that WBC count of $3.0 \times 10^{3}$ cells $/ \mathrm{mm}^{3}$ can be used as the cutoff level for screening cases with reduced WBC counts. Taking a conventional criterion of $4.0 \times 10^{3} \mathrm{WBCs} / \mathrm{mm}^{3}$ as the lower limit of the normal range for WBC counts [6], 7,206 and 3,256 cases of total $(5.52 \%)$ and never-smoking men $(7.99 \%)$ in 2010, respectively, would be below the limit. With a tentative limit of $3.5 \times 10^{3}$ cells $/ \mathrm{mm}^{3}$, the prevalence would be 2,152 cases $(1.65 \%)$ and 984 cases $(2.41 \%)$, respectively.

WBC counts have been a focus of medical attention since as early as the 1910s. In practice, 15 articles reporting WBC counts of Japanese men at the time of the study were available through literature survey [6, 9-22]; they are tabulated in Table 3 in combination with the present results. The target populations were men in many cases, whereas WBC counts for women were reported either separately or in combination with those for men. In most of the reports, the results were presented in terms of AM and ASD. Breakdown by decades of years of age were also presented in selected cases [9-13], and the results of such cases are presented as a range of AM values in Table 3.

Perusal of Table 3 suggests that WBC counts appear to be reducing with time. For quantitative evaluation of a possible secular trend of the decrease, one representative value was selected for each article. In cases where AM values were shown as a range, an arithmetic mean of the 
Table 1 Basic parameters

\begin{tabular}{|c|c|c|c|c|c|c|c|c|c|c|c|}
\hline \multirow{2}{*}{$\begin{array}{l}\text { Year of study } \\
\text { Group by smoking }\end{array}$} & \multirow[t]{2}{*}{ No. of cases } & \multicolumn{3}{|c|}{ Age (years) } & \multicolumn{7}{|c|}{ White blood cell counts $\left(\right.$ cells $/ \mathrm{mm}^{3}$ ) } \\
\hline & & $\mathrm{AM}$ & ASD & $p$ & $\mathrm{AM}$ & ASD & 2.5 percentile & 5.0 percentile & 95.0 percentile & 97.5 percentile & $p$ \\
\hline \multicolumn{12}{|l|}{2002} \\
\hline Total & 103,492 & 43.0 & 12.0 & \multirow{4}{*}{$\begin{array}{l}\mathrm{a} \\
\mathrm{a}, \mathrm{b}\end{array}$} & 6,248 & 1,751 & 2,325 & 2,815 & 9,681 & 10,171 & \multirow{4}{*}{$\begin{array}{l}\mathrm{a} \\
\mathrm{a}, \mathrm{b}\end{array}$} \\
\hline Never smokers & 34,298 & 42.5 & 12.3 & & 5,609 & 1,373 & 2,534 & 2,918 & 8,299 & 8,684 & \\
\hline Former smokers & 12,665 & 47.9 & 11.7 & & 5,713 & 1,384 & 2,613 & 3,001 & 8,424 & 8,812 & \\
\hline Current smokers & 56,529 & 42.2 & 11.7 & & 6,756 & 1,864 & 2,581 & 3,103 & 10,409 & 10,931 & \\
\hline \multicolumn{12}{|l|}{2010} \\
\hline Total & 130,431 & 44.2 & 11.7 & & 6,162 & 1,719 & 2,311 & 2,793 & 9,531 & 10,012 & \\
\hline Never smokers & 40,748 & 41.2 & 11.6 & \multirow[b]{2}{*}{$\mathrm{a}$} & 5,666 & 1,412 & 2,503 & 2,899 & 8,434 & 8,829 & \multirow[b]{2}{*}{$\mathrm{a}$} \\
\hline Former smokers & 36,041 & 48.3 & 11.1 & & 5,750 & 1,441 & 2,522 & 2,925 & 8,575 & 8,979 & \\
\hline Current smokers & 53,642 & 43.7 & 11.5 & $\mathrm{a}, \mathrm{b}$ & 6,815 & 1,884 & 2,596 & 3,123 & 10,507 & 11,034 & $\mathrm{a}, \mathrm{b}$ \\
\hline
\end{tabular}

${ }^{\mathrm{a}} p$ for difference from never smokers by Scheffé; for $p \leq 0.01$

${ }^{\mathrm{b}} p$ for difference from former smokers by Scheffé; for $p \leq 0.01$

Table 2 White blood cell counts (cells $/ \mathrm{mm}^{3}$ ) by decade of age of never smokers

\begin{tabular}{|c|c|c|c|c|c|c|c|c|c|c|c|c|}
\hline \multirow{3}{*}{$\begin{array}{l}\text { Group by } \\
\text { decade of age } \\
\text { (years) }\end{array}$} & \multicolumn{12}{|c|}{ Year of study } \\
\hline & \multicolumn{6}{|l|}{2002} & \multicolumn{6}{|l|}{2010} \\
\hline & No. ${ }^{a}$ & $\mathrm{AM}$ & ASD & 5 percentile & 95 percentile & $p^{\mathrm{b}}$ & No. ${ }^{a}$ & $\mathrm{AM}$ & ASD & 5 percentile & 95 percentile & $p^{\mathrm{b}}$ \\
\hline $20-29$ & 5,762 & $5,728.2$ & $1,434.6$ & 2,916 & 8,540 & & 7,455 & $5,846.5$ & $1,459.0$ & 2,987 & 8,706 & \\
\hline $30-39$ & 10,031 & $5,600.8$ & $1,382.5$ & 2,891 & 8,311 & $\downarrow \downarrow$ & 11,563 & $5,685.5$ & $1,414.0$ & 2,914 & 8,457 & $\downarrow \downarrow$ \\
\hline $40-49$ & 7,367 & $5,539.5$ & 1,333.6 & 2,926 & 8,153 & $\downarrow \downarrow$ & 12,173 & $5,588.8$ & $1,384.3$ & 2,876 & 8,302 & $\downarrow \downarrow$ \\
\hline $50-59$ & 8,134 & $5,603.4$ & $1,368.0$ & 2,922 & 8,285 & $\uparrow \uparrow$ & 6,440 & $5,606.3$ & $1,382.3$ & 2,897 & 8,316 & ns \\
\hline $60-69$ & 2,542 & $5,613.8$ & $1,303.8$ & 3,058 & 8,169 & ns & 2,787 & $5,587.3$ & $1,419.9$ & 2,804 & 8,370 & ns \\
\hline $70-79$ & 414 & $5,462.3$ & $1,342.3$ & 2,831 & 8,093 & $\downarrow$ & 319 & $5,599.7$ & $1,402.0$ & 2,852 & 8,348 & ns \\
\hline $80+$ & 48 & $5,391.7$ & $1,411.9$ & 2,624 & 8,159 & ns & 11 & $5,427.3$ & $1,530.4$ & 2,428 & 8,427 & ns \\
\hline
\end{tabular}

a Number of cases

b $p$ for difference from the immediately younger group by Scheffé; two arrows, one arrow, and ns show $p \leq 0.01, \leq 0.05$, and $>0.05$, respectively. The direction of arrows indicates an increase or a decrease

lower and upper limit values was taken. As sex difference in WBC counts has been considered as insignificant among Japanese populations (e.g., [6]), the values for men and women in combination (shown as $\mathrm{M}+\mathrm{W}$ in Table 3 ) were taken, whereas values for women only in Table 3 were not taken up because values for women were always accompanied by values for men.

WBC counting was conducted manually in early time studies, whereas it is presently by use of automated cell counters. Possible method-dependent difference was, however, not taken into account as it was reported that no differences in the results were observed between manual and instrumental counting [23], while no information on the method of counting was available for each report in the literature.

A linear regression analysis was conducted, taking year of publication and WBC counts on the horizontal and vertical axis, respectively (Fig. 2a); the data cited from Asai et al. [11] were prepared by Hibino in 1954-1955, and therefore the year 1954-1955 was taken in preparing Fig. 2. The publication year and WBC counts correlated significantly ( $r=0.581, p<0.05, n=16)$ with a calculated regression line of $Y=25518-9.538 X$, where $X$ is the year of publication and $Y$ is the reported WBC counts. Worthy of note in Fig. 1 is that the slope is negative (i.e., $<0$ ), and that the present study results for 2002 and 2010 lie between the regression line and the curve for the lower limit of the $95 \%$ range of the regression line. As a result, in 2010 for example, the prevalence of those with less than $4,000 \mathrm{WBC} / \mathrm{mm}^{3}$ is as high as $8 \%$ among never-smoking men, as discussed above. Thus, care should be practiced in making diagnosis of leukocytopenia, e.g., for radiation-exposed subjects.

It was considered possible that concepts and practice of statistical analysis made substantial progress in the late 
Table 3 Historical review of reference values for WBC counts in healthy Japanese

\begin{tabular}{|c|c|c|c|c|c|c|c|c|}
\hline \multirow[t]{2}{*}{ Authors } & \multirow[t]{2}{*}{ Years } & \multirow[t]{2}{*}{ Ref. } & \multirow{2}{*}{$\begin{array}{l}\text { Sex }(\mathrm{M} \text { for } \\
\text { men, W for } \\
\text { women })\end{array}$} & \multicolumn{4}{|c|}{ WBC counts $\left(\right.$ cells $\left./ \mathrm{mm}^{3}\right)$} & \multirow[t]{2}{*}{ Notes } \\
\hline & & & & $\mathrm{AM}$ & ASD & Min. & Max. & \\
\hline Masai & 1914 & {$[14]$} & M & 7,473 & & 4,220 & 12,600 & Healthy medical students \\
\hline Kura & 1925 & {$[15]$} & M & 7,718 & & 4,200 & 12,900 & Healthy army soldiers \\
\hline Kitajima & 1928 & [9] & $\mathrm{M}+\mathrm{W}$ & $5,981-7,827^{\mathrm{a}}$ & & 4,200 & 12,437 & $\begin{array}{l}\text { Healthy men and women of various } \\
\text { occupations aged } 20-60 \text { years }\end{array}$ \\
\hline \multirow[t]{2}{*}{ Komiya } & 1938 & {$[6]$} & & & & 4,000 & 10,000 & Statement in a textbook \\
\hline & & {$[6]$} & & & & 6,000 & 8,000 & \\
\hline Miyazu & 1943 & {$[10]$} & $\mathrm{M}+\mathrm{W}$ & $6,652-7,295^{\mathrm{a}}$ & & 4,700 & 13,800 & Healthy subjects \\
\hline Asai et al. & 1974 & [11] & M & $6,000-7,000^{\mathrm{b}}$ & & $<4,000$ & $>11,000$ & $\begin{array}{l}\text { Citation of the study by Hibino which was } \\
\text { conducted in } 1954-1955\end{array}$ \\
\hline \multirow[t]{2}{*}{ Miyasaka } & 1957 & [12] & M & $6,616-6,933$ & & 4,000 & 10,000 & \\
\hline & 1957 & [12] & W & $6,545-6,870$ & & 3,500 & 9,000 & \\
\hline \multirow{2}{*}{$\begin{array}{l}\text { Maekawa } \\
\text { and } \\
\text { Kinugasa }\end{array}$} & 1957 & [16] & $M+W$ & 6,480 & 1,110 & & & $\leq 60$ years \\
\hline & 1957 & {$[16]$} & $\mathrm{M}+\mathrm{W}$ & 6,680 & 110 & & & $18-30$ years \\
\hline \multirow[t]{2}{*}{ Inoue et al. } & 1959 & {$[17]$} & M & 6,314 & 1,375 & $2,550-3,000$ & $13,350-13,800$ & $\begin{array}{l}\text { Adult healthy workers; min. and max. } \\
\text { values are shown by ranges }\end{array}$ \\
\hline & 1959 & [17] & W & 6,286 & 1,465 & $2,550-3,000$ & $12,000-12,450$ & $\begin{array}{l}\text { Adult healthy workers; min. and max. } \\
\text { values are shown by ranges }\end{array}$ \\
\hline \multirow{2}{*}{$\begin{array}{l}\text { Shirakura } \\
\text { et al. }\end{array}$} & 1978 & [18] & M & 6,949 & 1,632 & & & \\
\hline & 1978 & {$[18]$} & W & 6,756 & 1,852 & & & \\
\hline \multirow[t]{2}{*}{ Goto et al. } & 1993 & [13] & M & $6,080-6,380$ & & 3,400 & 9,190 & \\
\hline & 1993 & [13] & W & $5,500-5,650$ & & 3,270 & 7,930 & \\
\hline \multirow[t]{2}{*}{ Okabe } & 1995 & [19] & M & 7,500 & 1,400 & & & Up to 59 years \\
\hline & 1995 & [19] & W & 7,600 & 1,100 & & & Up to 59 years \\
\hline Shiga et al. & 1999 & {$[20]$} & $\mathrm{M}+\mathrm{W}$ & 6,800 & & 2,900 & 10,700 & $\begin{array}{l}\text { Minimum and maximum values reported } \\
\text { for each of decades of years of age } \\
\text { (20-69 years) }\end{array}$ \\
\hline $\begin{array}{l}\text { Hasegawa } \\
\text { et al. }\end{array}$ & 2002 & {$[21]$} & $\mathrm{M}+\mathrm{W}$ & 5,795 & 1,521 & & & See footnote $\mathrm{c}$ \\
\hline \multirow{2}{*}{$\begin{array}{l}\text { Tatsukawa } \\
\text { et al. }\end{array}$} & 2008 & {$[22]$} & M & 6,700 & 1,700 & & & \\
\hline & 2008 & [22] & W & 6,000 & 1,600 & & & \\
\hline \multirow{4}{*}{$\begin{array}{l}\text { The } \\
\text { present } \\
\text { study }\end{array}$} & 2002 & & M & 6,248 & 1,751 & & & $\begin{array}{l}\text { 20-60-year-old men (for details, see } \\
\text { Table 1) }\end{array}$ \\
\hline & 2002 & & $\begin{array}{l}\text { M (never } \\
\text { smokers) }\end{array}$ & 5,609 & 1,373 & & & $\begin{array}{l}\text { 20-60-year-old never-smoking men (for } \\
\text { details, see Table 1) }\end{array}$ \\
\hline & 2010 & & M & 6,162 & 1,719 & & & $\begin{array}{l}\text { 20-60-year-old men (for details, see } \\
\text { Table 1) }\end{array}$ \\
\hline & 2010 & & $\begin{array}{l}\text { M (never } \\
\text { smokers) }\end{array}$ & 5,666 & 1,412 & & & $\begin{array}{l}\text { 20-60-year-old never-smoking men (for } \\
\text { details, see Table 1) }\end{array}$ \\
\hline
\end{tabular}

${ }^{a}$ Variation by decades of age, with no consistent age-dependent trends

b The range of modes for each of decades of years of age (20-59 years)

${ }^{c}$ Data on smokers and nonsmokers were combined by the present authors for a whole group

1940s. Thus, the studies conducted in 1950+ were re-evaluated separately from previous studies. The regression analysis (Fig. 2b) gave a calculated regression line of $Y=12,544-3.023 X \quad(r=0.150, \quad p>0.05, \quad n=12)$, where $X$ is the year of publication and $Y$ is the reported WBC counts. Although the slope appeared to be less steep (i.e., -3.023 ), it was negative (i.e., $<0$ ) and did not differ significantly $(p<0.05)$ from the slope $(-9.538)$ for total cases. The absence of the difference might be due to wide variation around the regression line. The lack of statistical significance of the correlation coefficient $(r=0.150, p>0.05)$ may be attributable at least in part 


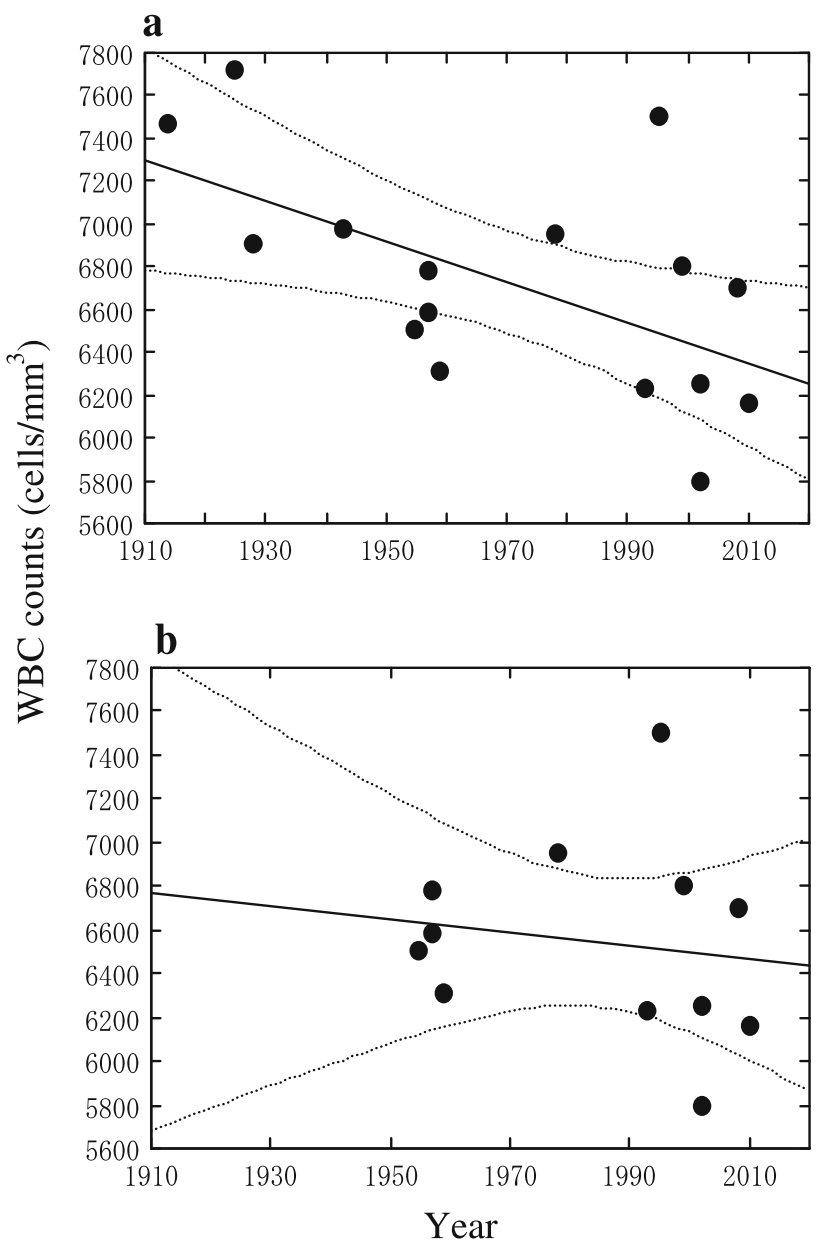

Fig. 2 Secular trends in average white blood cell counts in peripheral blood of adult male Japanese subjects. Each dot in the figure represents a representative arithmetic mean value in a report. See the text for selection of each represent value. The line in the middle of the figure is a calculated regression line, and two dotted curves on both sides of the line show the $95 \%$ range for the means

to the narrowing of the study year range from 96 to 55 years.

No reports were available on secular trend analyses in WBC counts for other (i.e., non-Japanese) populations. In the years around 2000, Bovill et al. [24] reported $6.2-6.4 \times 10^{3}$ cells $/ \mathrm{mm}^{3}$ for men, and 6.1-6.2 $\times$ $10^{3}$ cells $/ \mathrm{mm}^{3}$ for women. In addition, van Oostrom et al. [25] reported $5.41 \times 10^{3}$ cells $/ \mathrm{mm}^{3}$ for healthy adult men. Compared with these levels, surveys in the years around 1980 reported somewhat higher levels. For example, Godwin et al. [26] observed in a large-scale survey that the means were $6.0-6.5 \times 10^{3}$ cells $/ \mathrm{mm}^{3}$ (with small agedependent variations) and that the minimum and the maximum were 3.5 and $12.0 \times 10^{3}$ cells $/ \mathrm{mm}^{3}$, respectively. Barrett et al. [27] found that the mean and the range for WBC counts were $6.3(4.2-11.2) \times 10^{3}$ cells $/ \mathrm{mm}^{3}$ for men and $6.8(4.0-10.4) \times 10^{3}$ cells $/ \mathrm{mm}^{3}$ for women. Galen [28] reported that mean WBC counts were 6.7 to
$7.0 \times 10^{3}$ cells $/ \mathrm{mm}^{3}$ (3.5 and $11.9 \times 10^{3}$ cells $/ \mathrm{mm}^{3}$ for 2.5 and 97.5 percentile, respectively). According to Giorno et al. [29], WBC counts were in ranges of 3.13$10.84 \times 10^{3}$ cells $/ \mathrm{mm}^{3}$ for men and $3.28-11.05 \times 10^{3}$ cells $/ \mathrm{mm}^{3}$ for women. Thus, it appears likely that higher WBC counts were reported in the years about 20 years ago than at present time, although the ethnic backgrounds of the populations studied might vary.

With regard to possible explanations for the secular decrease in WBC counts in Japan, it is quite conceivable that at least two factors have been involved, i.e., infectious diseases and smoking. First, the decrease may be associated with reduced prevalence of infectious diseases, as WBC counts are known to increase in response to infections. For example, the Ministry of Health, Labor, and Welfare, Japan recorded $533 \times 10^{3}$ cases of patients with infectious diseases (including parasitosis and tuberculosis) in 1953. The number stayed at a high level of $563 \times 10^{3}$ cases in 1963 , but was reduced to $219 \times 10^{3}$ cases in 2008 [30-32]. No separate statistics are available for parasitosis among adult population. School health statistics, however, suggest an even more dramatic improvement in hygienic conditions. Namely, the percentage for 6-8-year-old children in primary schools who had eggs of gastrointestinal tract parasites was $50.7 \%$ in 1953, which dropped to $17.9 \%$ in 1963 and $0.4 \%$ in 2008 [33-35].

Another possible cause of reduction in WBC counts is the increase in the never-smoking ratio, as previously pointed out by Schwartz et al. [36]. Articles are accumulating to report that smoking induces an increase in WBC counts, although this may not be due to inflammation of the respiratory tract [37]. Thus, Smith et al. [38] observed that WBC counts were higher $\left(7.4 \times 10^{3}\right.$ cells $\left./ \mathrm{mm}^{3}\right)$ among 839 male current smokers than among 2,421 male never smokers $\left(6.2 \times 10^{3}\right.$ cells $\left./ \mathrm{mm}^{3}\right)$. The value for 3,597 former smokers $\left(6.4 \times 10^{3}\right.$ cells $\left./ \mathrm{mm}^{3}\right)$ was between the current and never smokers. A similar difference was observed among 925 current, 2,688 former, and 4,721 never-smoking women $\left(7.4,6.3\right.$, and $6.2 \times 10^{3}$ cells $/ \mathrm{mm}^{3}$, respectively).

Ishizaka et al. [39] also showed higher WBC counts $\left(6.3 \times 10^{3}\right.$ cells $\left./ \mathrm{mm}^{3}\right)$ among 1,158 current smokers (men and women combined) as compared with the counts in 1,130 former smokers $\left(5.3 \times 10^{3}\right.$ cells $\left./ \mathrm{mm}^{3}\right)$ and 1,399 never smokers $\left(5.1 \times 10^{3}\right.$ cells $\left./ \mathrm{mm}^{3}\right)$. The WBC counts correlated significantly $(p<0.01)$ with current smoking after logistic regression analysis [40]. Similarly, Al-Awadhi et al. [41] found in a small-scale epidemiology study with 49 smokers ( 31 men and 18 women) and 43 nonsmokers (24 men and 19 women) that WBC counts were higher in smokers than in nonsmokers $(p<0.05)$. Lee et al. [42] made a survey of community residents near nuclear power plants. WBC counts were higher for 
smokers $\left(6.7 \times 10^{3}\right.$ cells $/ \mathrm{mm}^{3}$ for 1,054 men and 86 women) than for nonsmokers $\left(6.3 \times 10^{3}\right.$ cells $/ \mathrm{mm}^{3}$ for 649 men and $6.1 \times 10^{3}$ cells $/ \mathrm{mm}^{3}$ for 1,813 women), although the effect of distance from the plants appeared to be negative (i.e., those who lived closer to the plants had higher WBC counts).

Thus, it appears to be prudent to conclude that smoking induces an increase in WBC counts, and that smoking cessation most probably results in reduction in WBC counts. During the period 1998-2008, for example, the smoking rate among male Japanese population gradually decreasing from $52.8 \%$ in 1998 [43] to $46.8 \%$ in 2003 [44] and $36.8 \%$ in 2008 [44].

Acknowledgments The authors are grateful to the administration and staff of Kyoto Industrial Health Association for their interest in and support of this work.

Conflict of interest The authors declare that they have no conflicts of interest.

\section{References}

1. Ward E, Hornung R, Morris J, Rinsky R, Wild D, Halperin W, et al. Risk of low red or white blood cell count related to estimated benzene exposure in a rubber worker cohort (1940-1978). Am J Ind Med. 1996;29:247-57.

2. Samoto S, Fukui Y, Ukai H, Okamoto S, Takada S, Ohashi F, et al. Field survey on types of organic solvents used in enterprises of various sizes. Int Arch Occup Environ Health. 2006;79:558-67.

3. Nagasawa Y, Ukai H, Okamoto S, Samoto H, Itoh K, Moriguchi $\mathrm{J}$, et al. Organic solvent use in research institutions in Japan. Ind Health. 2011;49:421-6.

4. Ministry of Health, Labour and Welfare, Japan. Ordinance for prevention of radiation hazards (enactment in 1922 (Order 41) and final revision in 2011 (Order 152)], 2011.

5. Bain B, Seed M, Godsland I. Normal values for peripheral blood white cell counts in women of four different ethnic origins. J Clin Pathol. 1984;3:188-93.

6. Komiya E. Textbook of clinical hematology. Tokyo: Kokuseido; 1938. p. 132. (in Japanese).

7. van den Bossche J, Devreese K, Malfait R, van de Vyvere M, Wauters A, Neeis H, et al. Reference intervals for a complete blood count determined on different automated haematology analysers: Abx Pentra 120 Retic, Counter Gen-S, Sysmex SE 9500, Abbott Cell Dyn 4000 and Bayer Advia 120. Clin Chem Lab Med. 2002;40:69-73.

8. Ichihara K. Statistics for bioscience. Nankodo, Tokyo, p. 218-223, 233; 1990 (in Japanese).

9. Kitajima N. Hematology of healthy Japanese with a focus on hemogram. Kumamoto Igakukai Zasshi (J Kumamoto Med Soc). 1928;19:63-82. (in Japanese).

10. Miyazu Y. Blood picture of health Japanese subjects-part 1. Kumamoto Igakkai Zasshi (J Kumamoto Med Soc). 1943;19: 485-524. (in Japanese).

11. Asai T, Kawakita Y, Meren E. Human leukocytes. Saishin Igaku (Modern Med). 1974;29:363-75. (in Japanese).

12. Miyasaka G. Normal blood picture of the Japanese. Nihon Ketsueki Gakkai Zasshi (Acta Haematol Jpn). 1957;720:105-18. (in Japanese with English abstract).
13. Goto K, Yasuno M, Ogura M, Kobayashi Y, Tsukada T, Tango T. Age and sex dependent distribution pattern and normal range of blood cell parameters obtained by automated blood cell analyzer. Rinso Byori. 1993;44:1146-52. (in Japanese with English abstract).

14. Masai Y. Hematology of healthy Japanese men. Tokyo Igakkai Zasshi (J Tokyo Med Soc). 1914;28:85-91. (in Japanese).

15. Kura G. Clinical significance of findings on leukocytes. Gunnidan Zasshi (J Military Med). 1925;146:965-96. (in Japanese).

16. Maekawa T, Kinugasa K. Hematological studies on the aged. Nihon Ketsueki Gakkai Zasshi (Acta Haematol Jpn). 1957;20:105-18. (in Japanese with English abstract).

17. Inoue $\mathrm{T}$, Abe $\mathrm{S}$, Hara I, Hibino $\mathrm{S}$, Horiguchi $\mathrm{S}$, Horiuchi $\mathrm{K}$, et al. Physiological values of the blood of the Japanese industrial workers. Sangyo Igaku (Jpn J Ind Health). 1959;1:384-422. (in Japanese with English abstract).

18. Shirakura T, Murai Y, Takeda T, Mori T. Changes of peripheral blood figures and erythropoiesis in the aged. Nihon Ronen Igaku Zasshi (Jpn J Geriatrics). 1978;15:151-7. (in Japanese with English abstract).

19. Okabe H. Characteristics of aged people in clinical biochemistry and hematology. Nihon Ishikai Zasshi (J Jpn Med Assoc). 1995;114:659-64. (in Japanese).

20. Shiga S, Koyanagi I, Osaga J, Ichiyama S, Kannagi R. Clinical reference values for laboratory hematology tests calculated using the iterative truncation method with correction: part 2. Reference values for white blood cell (WBC) count, WBC differential including segmented neutrophil, band neutrophil, lymphocyte, monocyte, eosinophil, basophil, platelet count and mean platelet volume. Rinso Byori. 1999;47:281-8. (in Japanese with English abstract).

21. Hasegawa T, Negishi T, Deguchi M. WBC count, atherosclerosis and coronary risk factors. J Atheroscler Thromb. 2002;9:219-23.

22. Tatsukawa Y, Hsu WL, Yamada M, Cologne JB, Suzuki G, Yamamoto $\mathrm{H}$, et al. White blood cell count, especially neutrophil count, as a predictor of hypertension in a Japanese population. Hypertens Res. 2008;31:1391-7.

23. Griswold DJ, Champagne VD. Evaluation of the coulter S-Plus $\mathrm{IV}^{\circledR}$ three-part differential in an acute care hospital. Am J Clin Pathol. 1985;84:49-57.

24. Bovill EG, Bild DE, Heiss G, Kuller LH, Lee MH, Rock R, et al. White blood cell counts in persons aged 65 years or more from the cardiovascular health study. Am J Epidemiol. 1996;143: $1109-15$.

25. van Oostrom AJHHM, Sijmonsma TP, Rabelink TJ, van Asbeck BS, Castro Cabezas M. Postprandial leukocyte increase in healthy subjects. Metabolism. 2003;52:199-202.

26. Godwin ID, Jencks JA. Normal hematologic values obtained with a coulter, model S. South Med. 1978;71:47-9.

27. Barrett AJ, Faille A, Ketels F. Variations in granulocyte colony forming cell numbers in adult blood. Br J Haematol. 1979;42: $337-44$.

28. Galen RS. Predictive value and efficiency of hematology data. Blood Cells. 1980;6:185-97.

29. Giorno R, Clifford JH, Beverly S, Rossing RG. Analysis by different statistical technics and variations with age and sex. Am J Clin Pathol. 1980;74:765-70.

30. Ministry of Health and Welfare, Japan. Patient Survey, 1953. Ministry of Health and Welfare, Tokyo; 1955 (in Japanese).

31. Ministry of Health and Welfare, Japan. Patient Survey, 1963. Ministry of Health and Welfare, Tokyo; 1965 (in Japanese).

32. Ministry of Health, Labour and Welfare, Japan. Patient Survey, 2008, Vol. 1. Ministry of Health, Labour and Welfare, Tokyo; 2010 (in Japanese).

33. Ministry of Education, Japan. School Health Statistics, 1953. Ministry of Finance Printing Bureau, Tokyo; 1954 (in Japanese). 
34. Ministry of Education, Japan. School Health Statistics, 1963. Ministry of Finance Printing Bureau, Tokyo; 1964 (in Japanese).

35. Ministry of Education, Culture, Sports, Science and Technology, Japan. School Health Statistics, 2008. Ministry of Education, Culture, Sports, Science and Technology, Tokyo; 2009 (in Japanese).

36. Schwartz J, Weiss ST. Cigarette smoking and peripheral blood leukocyte differentials. Ann Epidemiol. 1994;43:236-42.

37. Asthana A, Johnson HM, Piper ME, Fiore MC, Baker TB, Stein $\mathrm{JH}$. Effects of smoking intensity and cessation on inflammatory markers in a large cohort of active smokers. Am Heart J. 2010;160:458-63.

38. Smith MR, Kinmonth A-L, Luben RN, Bingham S, Day NE, Wareham J, et al. Smoking status and differential white cell count in men and women in the EPIC-Norfolk population. Atherosclerosis. 2003;169:331-7.

39. Ishizaka N, Ishizaka Y, Toda E, Nagai R, Yamakado M. Association between cigarette smoking, white blood cell count, and metabolic syndrome as defined by the Japanese criteria. Int Med. 2007;46:1167-70.
40. Ishizaka N, Ishizaka Y, Toda E, Nagai R, Koike K, Hashimoto H, et al. Relationship between smoking, white blood cell count and metabolic syndrome in Japanese women. Diabet Res Clin Pract. 2007;78:72-6.

41. Al-Awadhi AM, AlFadhli SM, Mustafa NY, Sharma PN. Effects of cigarette smoking on hematological parameters and von Willebrand factor functional activity levels in asymptomatic male and female Arab smokers. Med Princ Pract. 2008;17:149-53.

42. Lee YT, Sung FC, Lin RS, Hsu HC, Chien KL, Yang CY, et al. Peripheral blood cells among community residents living near nuclear power plants. Sci Total Environ. 2001;280:165-72.

43. Ministry of Health, Labour and Welfare, Japan. Smoking and Health Survey, 1998. Ministry of Health Labour and Welfare, Tokyo; 1999 (in Japanese).

44. Ministry of Health, Labour and Welfare, Japan. National Nutrition Survey, 2008. Dai-ichi Shuppann Publishers, Tokyo; 2011 (in Japanese). 